\title{
Article
}

Mycosphere

Doi 10.5943/mycosphere/7/3/2

Copyright (C) Guizhou Academy of Agricultural Sciences

\section{A new species of Amanita growing under Eucalyptus is discovered in South Brazil}

\author{
Wartchow $\mathbf{F}^{1 *}$ and Cortez $\mathbf{V G}^{2}$ \\ ${ }^{1}$ Universidade Federal da Paraíba, Departamento de Sistemática e Ecologia, 58051-970, João Pessoa, PB, Brazil \\ ${ }^{2}$ Universidade Federal do Paraná, Departamento de Biodiversidade, 85950-000, Palotina, PR, Brazil
}

Wartchow F, Cortez VG 2016 - A new species of Amanita growing under Eucalyptus is discovered in South Brazil. Mycosphere 7(3), 262-267, Doi 10.5943/mycosphere/7/3/2

\begin{abstract}
Amanita aliena is described as new species from a Eucalyptus plantation in South Brazil. It belongs to subgenus Amanita where it has an isolate phenetic position, due to distinct morphology: yellowish brown pileus, universal veil as wart forming broken collars on the top of bulb from the junction to stipe base to near base, large basidiospores (7.5-) 8.5-14.5 (-16) × (5.7-) 6-9.5 (-11) $\mu \mathrm{m}$, subhymenium with non-inflated cells and scarcity of clamp connection at base of basidia.
\end{abstract}

Key words - Amanitaceae - Agaricales -Agaricomycetes - taxonomy

\section{Introduction}

In South Brazil, Amanita Pers. has been studied more recently. Wartchow et al. (2013a) reported two subspecies of $A$. muscaria (L.) Lam. (subsp. muscaria and subsp. flavivolvata Singer), and Wartchow et al. (2013b) described A. petalinivolva Wartchow (subgenus Amanita). Other six taxa also are referred from this region: A. chrysoleuca Pegler, A. multisquamosa Peck (subgen. Amanita), A. grallipes Bas \& de Meijer, A. strobiliformis (Paulet ex Vittad.) Bertill. (subgen. Lepidella), A. rubescens Pers. and A spissa (Fr.) Bertill. (subgen. Validae) (Rick 1906, 1937, Bas \& de Meijer 1993, Giachini et al. 2000, Sobestiansky 2005, de Meijer 2006). It is notable that most recorded species of Amanita from South Brazil (e.g., A. muscaria, A. multisquamosa and A. rubescens) are ectomycorrhizal partners of exotic Pinus and Eucalyptus, the most cultivated trees in that region (Sulzbacher et al. 2013). During mycological fieldwork in South Brazil, an interesting species of Amanita growing under Eucalyptus plantation was collected, which could not be determined at that time. This material was considered as belonging to a new taxonomic entity, which is described in the present paper.

\section{Materials \& Methods}

The specimen was collected in a Eucalyptus plantation at the municipality of Minas do Leão, placed in the Pampa biome of South Brazil. Generic and infrageneric names and concepts follow Yang (1997). The methodology of Tulloss (2000), for biometric measurements and biometric variable names - summarized by Tulloss \& Lindgren (2005) - was followed, as slightly modified by Wartchow \& Gamboa-Trujillo (2012). Terminology used for Amanita are according Wartchow et al. (2013b). The holotype is deposited at ICN and a probable second collection of the new species is at FLOR (Thiers 2016). 


\section{Taxonomy}

Amanita aliena Wartchow \& Cortez, sp. nov.

MycoBank \#815753

Type - Brazil, Rio Grande do Sul, Minas do Leão, Agropecuária Condor, 26 May 2008, V.G. Cortez 094/08 (ICN 170790 holotypus hic designatus!).

Etymology - from Latin ('aliena' = foreign).

Basidiome medium size. Pileus $80 \mathrm{~mm}$ wide and $40 \mathrm{~mm}$ high, hemispheric, pale yellowishbrown; margin indistinctly sulcate (about $5 \mathrm{~mm}$ long); context probably whitish, unchanging; universal veil as adnate, cream to ochraceus-brown, pyramidal warts, unchanging. Lamellaenarrowly adnexed, forming decurrent tooth at stipe apex, whitish to cream with concolorous edge, unchanging, crowded; lamellulae truncate, with several lengths. Stipe $40 \times 30$ $\mathrm{mm}$, narrowing upwards, white, unchanging, surface smooth; bulb $50 \mathrm{~mm}$ high, $40 \mathrm{~mm}$ wide (in the widest portion), subglobose; context probably whitish, unchanging, solid (observed at exsiccate); partial veil white, apical, smooth with universal remnants at edge; universal veil as wart forming concentric broken collars, cream to ochraceous-brown on the top of bulb from the junction to stipe base to near base; "limbus internus" close to partial veil, concolorous to universal veil. Odorand Taste not performed.

Basidiospores [60/1/1] (7.5-) 8.5-14.5 (-16) $\times(5.7-) 6-9.5(-11) \mu \mathrm{m},(\mathbf{L}=10.8 \mu \mathrm{m} ; \mathbf{W}=$ $7.2 \mu \mathrm{m} ; \mathrm{Q}=(1.14-)$ 1.28-1.71 (-1.82); $\mathbf{Q m}=1.50)$, inamyloid, hyaline, colorless, ellipsoid occasionally to frequently elongate occasionally broadly ellipsoid, smooth, wall about $0.4 \mu \mathrm{m}$ thick, usually at least somewhat adaxially flattened; apiculus obtuse, prominent somewhat large, sub lateral to almost apical; contents somewhat one or two large guttules. Basidia 39.5-48 ×9.5-11 $\mu \mathrm{m}$, 4- somewhat 2-sterigmate, with sterigmata $3.5 \mu \mathrm{m}$ long, clamps infrequent at base. Subhymenium $22 \mu \mathrm{m}$ thick, with frequently uninflated cells e.g. $8 \times 5 \mu \mathrm{m}$, to occasionally more inflated clavate, up to $15 \times 11 \mu \mathrm{m} ; \mathbf{w}_{\mathbf{s t}}$-near $=47-57 \mu \mathrm{m} ; \mathbf{w}_{\mathbf{s t}}-\mathbf{f a r}=54-68 \mu \mathrm{m}$. Lamella trama bilateral; $\mathbf{w}_{\mathbf{c s}}=25 \mu \mathrm{m}$; filamentous hyphae up to $2-4(-8) \mu \mathrm{m}$ wide infrequently thickening to 14 $\mu \mathrm{m}$, diverging abruptly and occasional slender clavate elements that range to $62 \times 15 \mu \mathrm{m}$; oleiferous hyphae slender to $4 \mu \mathrm{m}$, very frequent. Marginal tissue on lamella edge not examined. Pileus context rehydrating satisfactorily; distinctly acrophysalidic; acrophysalides to 90-110 $\times 25-$ $50 \mu \mathrm{m}$ slender fusoid to fusoid, very common; filamentous hyphae $2-9 \mu \mathrm{m}$ wide, common, usually branched, very interwoven, occasionally clamped; oleiferous hyphae 4-14 $\mu \mathrm{m}$, frequent. Stipe context rehydrating satisfactorily; longitudinally acrophysalidic; acrophysalides 65-220 × 35-70 $\mu \mathrm{m}$, common, wall thickening to $1 \mu \mathrm{m}$; filamentous hyphae 4-12 $\mu \mathrm{m}$, longitudinally oriented but somewhat branched, very common; oleiferous hyphae 5-12 $\mu \mathrm{m}$ wide, with more or less longitudinal orientation, very common, mostly toward apex. Pileipellis a cutis ranging to $200 \mu \mathrm{m}$ at pileus centre; suprapellis an ixocutis up to $70 \mu \mathrm{m}$ thick with interwoven filamentous hyphae 1.5-4 $\mu \mathrm{m}$, colorless, with a more or less radial orientation to more diffuse at apex to more or less anticlinal, somewhat gelatinized, oleiferous hyphae absent; subpellis up to $130 \mu \mathrm{m}$ radially oriented, filamentous hyphae up to $2-4 \mu \mathrm{m}$ wide, plentiful; yellow-brown more diffuse and interwoven; oleiferous hyphae frequent 4-11 $(-16) \mu \mathrm{m}$ wide. Universal veil On pileus: inflated cells elongate $80 \times 28 \mu \mathrm{m}$, or ovoid $50 \times 34 \mu \mathrm{m}$, hyaline, orientation more or less anticlinal; filamentous hyphae e 2-6 $\mu \mathrm{m}$, hyaline, common; oleiferous hyphae absent. Above bulb ("limbus internus"): inflated cells $20-88 \times 13-44 \mu \mathrm{m}$, ovoid to elliptic, colorless; filamentous hyphae up to 2-8 $\mu \mathrm{m}$, hyaline, abundant; oleiferous hyphae occasional to $4 \mu \mathrm{m}$ wide. Universal veil on bulb: inflated cells subglobose $15-58 \times 14-55 \mu \mathrm{m}$, sometimes ovoid $(50 \times 38 \mu \mathrm{m})$, colorless, abundant; filamentous hyphae to $7 \mu \mathrm{m}$, thin-walled, hyaline, very interwoven, abundant; oleiferous hyphae absent. Partial veil filamentous hyphae up to $2-5 \mu \mathrm{m}$, strongly interwoven, ramified, abundant; terminal inflated elements difficult to locate, elongate-clavate to subcylindric $(44 \times 12 \mu \mathrm{m})$; edge with abundant inflated cells of the universal veil; oleiferous hyphae $4 \mu \mathrm{m}$ wide, very occasional.

Habit - solitary on soil, under Eucalyptus sp. plantation, in the biome Pampa. 


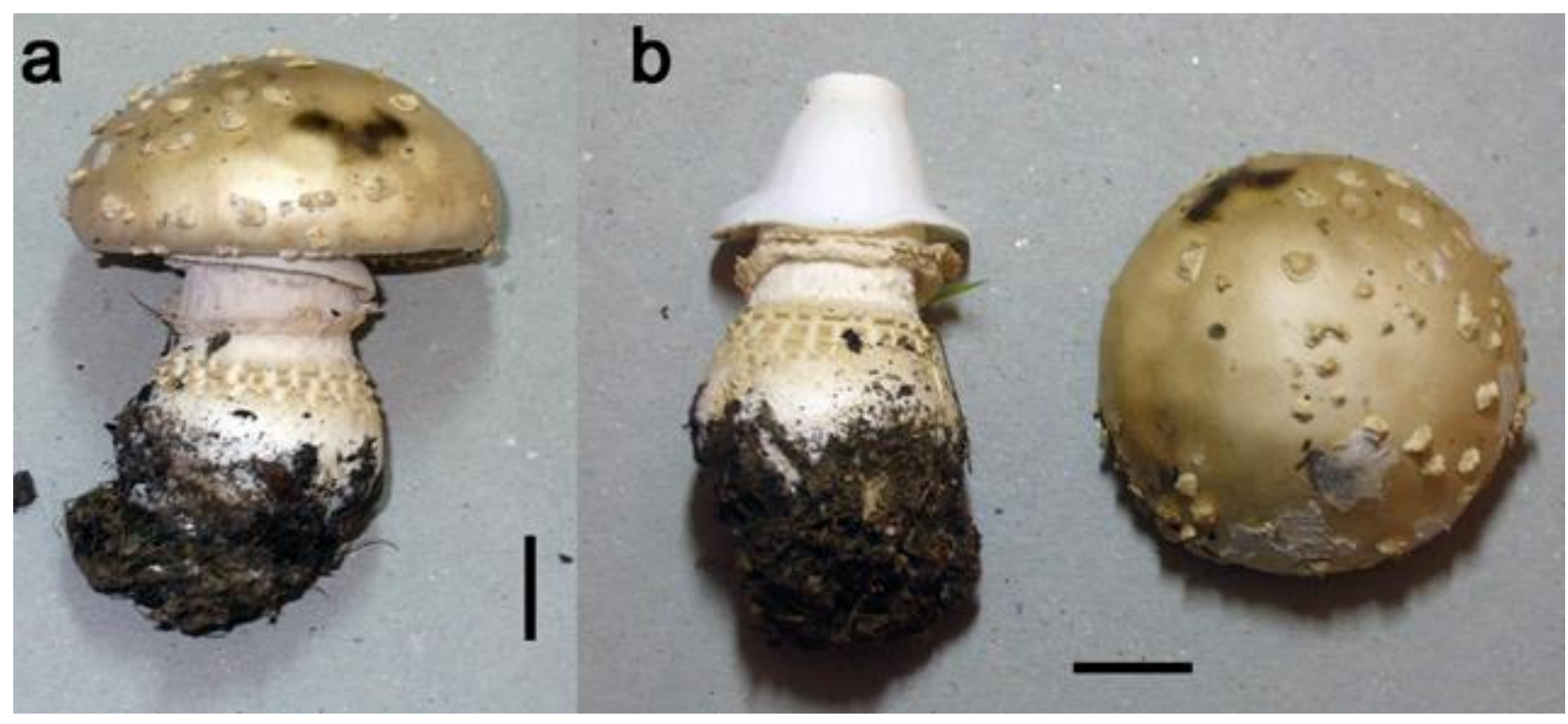

Fig. 1 - Amanita aliena (holotype). a, b: Basidiome. Bars $=10 \mathrm{~mm}$.

\section{Catarina.}

Known distribution - south Brazil, from the States of Rio Grande do Sul and Santa

Additional material examined - Brazil, Santa Catarina, Correia Pinto, 10 July 1996, A.J. Giachinis.n. (FLOR 31461, as Amanita pantherina var. multiscamosa).

Notes - Amanita aliena is diagnosed by the combination of the following morphological features: pale yellowish brown pileus, universal veil as wart forming broken collars on the top of bulb from the junction to stipe base to near base, basidiospores (7.5-) 8.5-14.5 (-16) $\times(5.7-)$ 6-9.5 $(-11) \mu \mathrm{m}$, subhymenium with uninflated cells and scarcity of clamp connection at base of basidia. Our first attempt was to treat A. aliena (sect. Amanita) as a muscaroid taxon due the habit and disposition of the universal veil on bulb, forming a broken collar. However, the scarcity of clamp connections segregates that new species from this group (Tulloss \& Yang 2016). Indeed, the occurrence of the 'limbus internus' on the stipe as like as an annulus resembles the one found in $A$. breckonii Thiers \& Ammirati, originally described from California (Thiers \& Ammirati 1982). However, A. breckonii is a typical muscaroid taxon, presenting abundant clamp connections in the basidia (Tulloss\& Yang 2016), and the similarities are only superficial. The basidiospores of booth taxa are somewhat similar: [320/16/3] (7.2-) 10-12.8 (-16.0) $\times(4.5-) 6.2-7.8(-9.0) \mu \mathrm{m},(\mathbf{L}=$ 10.9-12 (-12.2) $\mu \mathrm{m} ; \mathbf{L}^{\prime}=11.3 \mu \mathrm{m} ; \mathbf{W}=(6.6-) 6.7-7.1(-7.2) \mu \mathrm{m} ; \mathbf{W}^{\prime}=6.9 \mu \mathrm{m} ; \mathbf{Q}=(1.31-) 1.47-$ 1.89 (-2.29); $\mathbf{Q}=(1.55-)$ 1.58-1.74 (-1.85); $\mathbf{Q m}=1.65)$, but $\mathbf{Q m}=1.50$ for $A$. aliena . In addition, other aspects differ $A$. breckonii from our new species: the universal veil from pileus as scattered to abundant, deciduous plaques or patches, flat, irregularly shape, while A. aliena presents pyramidal warts; the universal veil from stipe as white, friable, low rim of tissue around the apex of the bulb in $A$. breckonii instead concentric broken collarswarts in our new species.

Certainly, A. aliena refers to a relatively isolated position among members of sect. Amanita based on the uncommon set of features mentioned above. Several works reported Amanitas growing under Eucalyptus but none report similar fungus as our new species (Miller 1991, 1992, Reid \& Eicker 1991, Ridley 1991, Grgurinovic 1997, Wood 1997, Neville \& Poumarat 2004, Davison 2011, Davison et al. 2013, 2015).

We found another material identified as A. pantherina var. multisquamosa (Peck) Dav. T. Jenkins (FLOR 31461), also collected under Eucalyptus; the basidiospores are very similar in size and shape to A. aliena: [40/1/1] (9.5-) 10-14 (-16) × (6.5-) 7-9.5 (-10) $\mu \mathrm{m}, \mathbf{L}=11.7 \mu \mathrm{m} ; \mathbf{W}=8.1$ $\mu \mathrm{m} ; \mathrm{Q}=(1.20-)$ 1.26-1.78 (-1.83); $\mathbf{Q m}=1.49$. However, no field notes accompany the exsiccate and the subhymenium is poorly rehydrated. However, the basidiospores size and the habitat growing under Eycalyptus might identify this material as A. aliena. Collection with field notes is necessary for confirmation of the identity of Santa Catarina's material. 


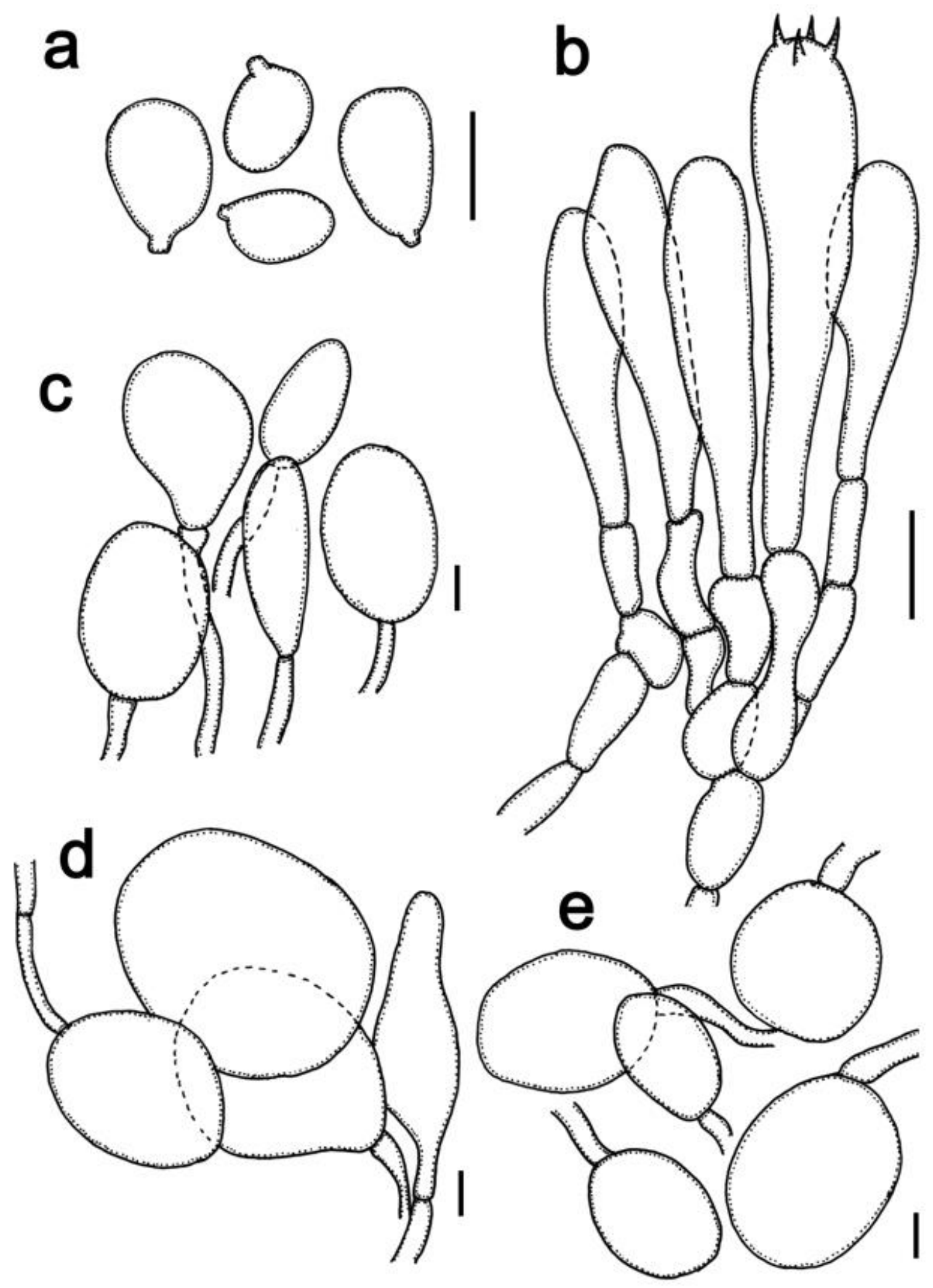

Fig. 2 - Amanita aliena (holotype). A Basidiospores. B Hymenium and subhymenium. C Universal veil elements of pileus. D Universal veil elements of stipe base. E Universal veil elements of the "limbus internus". Bars $=10 \mu \mathrm{m}$.

In Brazil, Wartchow et al. (2013a) reported specimen of A. muscaria subsp. flavivolvata growing under Eucalyptus forest in Rio Grande do Sul State. Amanita aliena, as described here is the second taxon found in this type of environment in the state. 


\section{Acknowledgements}

The first author thanks Dr. Rodham E. Tulloss (New Jersey) for his guidance in the studies of Amanita, and Dr. Leonor C. Maia and Dr. Maria Auxiliadora Q. Cavalcanti for supervision during PhD. The authors thank curator of FLOR for loan specimens and Dr. Jefferson Prado (IBt-SP) for nomenclatural advice. This work was supported by CNPq (PROTAX - Grant 141073/2006-3).

\section{References}

Bas C, de Meijer AAR. 1993 - Amanita grallipes, a new species in Amanita subsection Vittadiniae from Southern Brazil. Persoonia 15, 345-350.

Davison EM. 2011 -Amanita ochroterra and Amanita brunneiphylla (Basidiomycota), one species or two? Nuytsia 21, 177-184.

Davison EM, McGurk LE, Bougher NL, Syme K, Watkin ELJ. 2013 -Amanita lesueurii and A. wadjukiorum (Basidiomycota), two new species from Western Australia, and expanded description of A. fibrillopes. Nuytsia 23, 589-606.

Davison EM, Giustiniano D, McGurk LE, Syme K, Robinson RM. 2015 -Amanita drummondii and A. quenda (Basidiomycota), two new species from Western Australia, and a expanded description of A. walpolei. Nuytsia 25, 1-13.

Giachini AJ, Oliveira VL, Castellano MA, Trape JM. 2000 - Ectomycorrhizal fungi in Eucalyptus and Pinus plantations in southern Brazil. Mycologia 92, 1166-1177.

Grgurinovic CA. 1997 - Larger Fungi of South Australia. The Botanic Gardens of Adelaide and State Herbarium \& The Flora and Fauna of South Australia Handbooks Committee, Adelaide.

de Meijer AAR. 2006 - Preliminary list of the macromycetes from the Brazilian State of Paraná. Boletim do Museu Botânico Municipal (Curitiba) 68, 1-55.

Miller OK Jr. 1991 - New species of Amanita from Western Australia. Canadian Journal of Botany 69, 2692-2703.

Miller OK Jr. 1992 - Three new species of Amanita from Western Australia. Mycologia 84, 679686.

Neville P, Poumarat S. 2004 - Amanitae: Amanita, Limacella \& Torrendia. Fungi Europaei 9. Edizioni Candusso, Alassio.

Reid DA, Eicker A. 1991 - South African fungi: the genus Amanita. Mycological Research 95, 8095.

Ridley GS. 1991 - The New Zealand species of Amanita (Fungi: Agaricales). Australian Systematic Botany 4, 325-354.

Rick J. 1906 - Pilze aus Rio Grande do Sul. Brotéria Série Botânica 5, 5-53.

Rick J. 1937 - Agarici Riograndensis. Lilloa 1, 307-346.

Sobestiansky G. 2005 - Contribution to a macromycete survey of the states of Rio Grande do Sul and Santa Catarina in Brazil. Brazilian Archives of Biology and Technology 48, 437-457.

Sulzbacher MA, Grebenc T, Jacques RJS, Antoniolli ZI. 2013 - Ectomycorrhizal fungi from southern Brazil - a literature-based review, their origin and potential hosts. Mycosphere 4, 61-95.

Thiers B. 2016 (continuously updated) - Index Herbariorum: A global directory of public herbaria and associated staff. New York Botanical Garden's Virtual Herbarium. http://sweetgum.nybg.org/ih/ [accessed 05February 2016].

Thiers HD, Ammirati JF. 1982 - New species of Amanita from Western North America. Mycotaxon 25, 155-166.

Tulloss RE. 2000 - Note sula metodologia per lo studio del genere Amanita (Agaricales). Boletino del Gruppo Micologico G. Bresadola 43, 41-58.

Tulloss RE, Lindgren JE. 2005 - Amanita aprica- a new toxic species from western North America. Mycotaxon 91, 193-205. 
Tulloss RE, Yang ZL. 2016 - Studies on Amanitaceae - amanitaceae.org [accessed 05February 2016].

Wartchow F, Gamboa-Trujillo JP. 2012 - Amanita chocoana- a new species from Ecuador. Mycotaxon 121, 405-412.

Wartchow F, Maia LC, Cavalcanti MAQ. 2013a - Taxonomic studies of Amanita muscaria (L.) Lam. (Amanitaceae, Agaricomycetes) and its infraspecific taxa in Brazil. Acta Botanica Brasilica 27, 31-39.

Wartchow F, Maia LC, Cavalcanti MAQ. 2013b - Studies on Amanita (Agaricomycetidae, Amanitaceae) in Brazil: two yellow gemmatoid taxa Nova Hedwigia 96, 61-71.

Wood AE. 1997 - Studies in the genus Amanita (Agaricales) in Australia. Australian Systematic Botany 10: 723-854.

Yang ZL. 1997 - Die Amanita-Arten von Südwestchina. Bibliotheca Mycologica 170, 1-240. 